УдК 343.301

\author{
С. П. Чумак
}

\title{
ОСОБЛИВОСТІ СПОСОБІВ УЧИНЕННЯ ЗЛОЧИНІВ, ПОВ'ЯЗАНИХ ІЗ ФАЛЬСИФІКАЦІЕЮ РЕЗУЛЬТАТІВ ВИБОРІВ
}

Постановка проблеми. Проблема аналізу достовірності результатів виборів і референдумів існувала в усіх країнах і в усі часи. Але для України та інших країн СНД ця проблема особливо актуальна. Передусім тому, що після кожних виборів з'являються численні заяви про грубі порушення процедури та фальсифікації. При цьому варто відзначити відсутність судових процесів, що можна пояснити декількома причинами. По-перше, заступництвом фальсифікаторів замовником цієї фальсифікації. По-друге, у більшості випадків практичною неможливістю піймати фальсифікатора «за руку». Якщо він поклав бюлетень «ванова» у стопку бюлетенів «Петрова» й наглядач це помітив, працівник виборчої комісії може послатися на втому чи автоматичну помилку.

Аналіз останніх досягнень і публікацій. Окремі питання протидії злочинам та іншим правопорушенням у сфері реалізації законодавства про вибори в контексті їх кримінально-правової кваліфікації, кримінологічної характеристики та профілактики досліджували Л.В. Гудзь, В.М. Колесніченко, А.М. Колодій, С.В. Красноголовець, О.В. Кубарева, О.В. Лавринович, С.Я. Лихова, Л.П. Медіна, М.І. Мельник, С.А. Мозоль, М.О. Мягков, М.Л. Ставнійчук, Ю.М. Тодика, М.І. Хавронюк та ін. Крім того, численні публікації за темою дослідження, що трапляються в засобах масової інформації, здебільшого мають публіцистичний характер.

Метою статті $є$ дослідження окремих способів учинення злочинів, пов'язаних із фальсифікацією результатів виборів.

Виклад основного матеріалу дослідження. Перш ніж виявити види способів фальсифікацій результатів виборів, потрібно визначити, що таке фальсифікація.

Поняття «фальсифікація» (від лат. falsificatio - підробка) означає вчинена $з$ корисливих мотивів підробка чогось, зміна вигляду або властивостей предмета й надання йому такого зовнішнього вигляду, який не відповідає його справжній сутності [4]. Фальсифікація передбачає підроблення, перекручення й розповсюдження фальшивої інформації та їїносіїв.

Аналіз матеріалів практики свідчить, що фальсифікація результатів виборів являє собою дії, які спрямовані на порушення всього виборчого 
процесу, а також порядку, що передбачений для отримання, заповнення виборчих бюлетенів і процесу голосування; процедури, передбаченої для підрахунку й затвердження результатів голосування чи процесу, визначеного для реєстрації виборців.

Поряд із терміном «фальсифікація», що стосується документів, використовуються терміни «підлог» і «підробка». У криміналістиці ж має місце використання останнього поняття.

Підробка є способом учинення багатьох злочинів, у тому числі й злочинів проти виборчих прав. Наведений спосіб є своєрідним обманом, який $є$ матеріально вираженим у виборчому документі. Такий обман учиняється зацікавленими особами заради того, щоб сторонні особи викривлену інформацію в документі сприймали за справжню.

Підробка виборчих документів в основному має комплексний характер. Так, виготовляється виборчий документ у протизаконний спосіб, потім до нього заносяться неправдиві відомості та здійснюється його інша підробка у вигляді проставляння печатки виборчої комісії. Після цього здійснюється його використання. Підробка є знарядійним способом учинення злочину. Це випливає з того, що під час будь-якого підроблення здійснюється вплив на матеріальні речі. I такий вплив завжди чиниться за допомогою засобів учинення злочину. Це можуть бути «звичайні» засоби та спеціально прилаштовані для вчинення конкретного різновиду підроблення. Під час підробки виборчої документації злочинці вдаються переважно до часткового підроблення, зміст якого полягає в підчищенні, виправленні, дописці, підробленні підписів, печаток і штампів. Будь-яку таку зміну, внесену в документ, злочинець прагне зробити непомітною й маскувати під загальний фон.

Існує дві форми підробки - виготовлення та перероблення. Але незалежно від форми всі підроблення вчинюються заради того, щоб сторонні особи сприймали підроблену річ за справжню.

Підробка як спосіб учинення злочину залежно від співвідношення 3 дією може виступати як внутрішній зміст злочинної дії, бути іманентною їй або виступати в ролі дії «допоміжного» характеру, що забезпечує виконання основної дії.

За особливостями зовнішньої сторони вчинення необхідно розрізняти матеріальну й інтелектуальну підробку.

Незначні порушення, які пов'язані з організацією та проведенням виборчих компаній, такі як неточності, допущені в агітаційній літературі, методи, до яких удаються кандидати, щоб змусити своїх політичних супротивників зняти свої кандидатури, чи нездатність членів виборчих комісій забезпечити дотримання процедур голосування під час штатних виборів, але без умислу, зазвичай не підпадають під категорію «фальсифікація виборів», однак є їі невід’ємною частиною.

Більшість випадків фальсифікації виборів відбувається у зв'язку з прагненням незаконним шляхом отримати посаду в місцевих органах влади, який забезпечує право призначення на посаду. Отже, дії щодо фальсифі- 
кації результатів виборів часто пов'язані з іншими злочинами, такими як захист і приховування незаконних дій, установленням і використанням корумпованих зв'язків в органах державної влади й управління.

Злочинні дії щодо фальсифікації результатів виборів зазвичай не мають місця в тих адміністративних підрозділах, де одна політична сила користується широкою підтримкою електорату, так як у таких випадках зазвичай не має необхідності вдаватися до різного роду махінацій і порушень для отримання посту в місцевих органах влади. Як раз, навпаки, фальсифікація виборів найбільш часто відбувається там, де виступають відносно рівні політичні сили, і там, де багато залежить від того, хто обійме цю державну посаду, як це часто трапляється під час виборів на «протекційні» пости, які $є$ основними джерелами отримання чи забезпечення прибутку.

Усі дії кандидатів до дня голосування є піаром або чорним піаром. Використання брудних технологій фактично легалізоване чинним законодавством про вибори, полягає в понятті і процедурі проведення передвиборчої агітації. При цьому в цей період дозволені заклики голосувати за кандидата, кандидатів, список, списки кандидатів або проти нього (них). Отже, заклик голосувати проти іншого кандидата так само розглядається як передвиборча агітація. До якої міри може поширюватися цей заклик?

Мабуть, до межі, за якою неминуча кримінальна відповідальність. Наприклад, наклеп кримінально карається. Але, з іншого боку, чи сильна відмінність між наклепом і спотворенням фактів? Або наклепом і замовчуванням?

Проте будь-які дії кандидатів у період передвиборчої агітації розглядаються як агітація. Фальсифікацією є лише підтасовування результатів виборів.

Усі випадки фальсифікаціі виборів у практичному застосуванні можна зарахувати до двох категорій:

- фальсифікація без участі в ній окремих виборців;

- фальсифікація із залученням виборців.

1. Фальсифікація виборів без залучення виборизів.

До цієї категорії належать ті випадки фальсифікації, коли виборці не беруть безпосередньої участі в цих махінаціях. До таких випадків належать заповнення виборчих скриньок підробленими бюлетенями, голосування «мертвих душ» і голосування «за пацієнтів приватних клінік». Докази таких злочинів великою мірою залежать від фактів і свідчень, отриманих у ході процесу голосування, і наявності зразків почерку осіб, які мають доступ до обладнання для голосування, отже, мають можливість використовувати його в корисливих цілях. Як правило, такі злочини вчиняються таким шляхом:

А) Унесення фіктивних імен до списків виборців на етапі їх складання. При цьому застосовуються такі прийоми:

- унесення даних про померлих людей, оскільки «мертві душі» дають змогу отримати підроблені бюлетені, які потім можуть бути кинуті у виборчі ящики; 
- використання фіктивних бюлетенів за осіб, що не проголосували;

- здобуття й заповнення бюлетенів для заочного голосування без активного залучення до цього правопорушення виборців. Бюлетені для заочного голосування можуть особливо легко бути використані для такого роду правопорушень, оскільки заповнення бюлетенів і голосування не вимагає присутності членів виборчих комісій. Водночас присутність спостерігачів під час цих процесів не забороняється.

Б. Застосування різних способів фальсифікації на етапі підведення підсумків голосування, а саме:

- «укидання» - підкидання додаткових бюлетенів на користь бажаного кандидата до початку голосування або в ході голосування.

Навіть якщо вони мають відмітки за різних кандидатів, але їх кількість перевищує кількість виборців, що проголосували по списках, то це практично автоматично призводить до скасування підсумків виборів на ділянці. Якщо ж «укидання» робить хто-небудь із членів виборчої комісії під одного з «потрібних» кандидатів, то кількість бюлетенів, звичайно, зійдеться. «Укидання» застосовується в останню хвилину перед закриттям дільниці для підрахунку голосів виборців (або до початку голосування в урнах уже знаходитимуться декілька десятків «правильних» бюлетенів). Це будуть свіжовіддруковані бюлетені з печаткою цієї ділянки або бюлетені тих виборців, що не прийшли голосувати;

- «хитрий палещь» - псування бюлетенів, заповнених на користь небажаного кандидата; цей варіант дає змогу непомітно для інших членів виборної комісії «псувати» бюлетені, ставлячи на них додаткові галочки або риски. Для цього використовують забинтований палець з авторучкою всередині, вуглину, заховану в долоні, й інші підсобні матеріали;

- перестановка результатів голосування, коли голоси, отримані кандидатом (партією) А, приписуються кандидатові (партії) Б. Голоси ж, отримані кандидатом (партією) Б, реєструються як отримані кандидатом (партією) А;

- «солянка» - підміна деякої кількості бюлетенів бюлетенями, заповненими на користь бажаного кандидата. Під час підрахунку голосів, поданих за кожного кандидата, пачки можуть спеціально переплутати або змішати хороші й зіпсовані бюлетені разом. Крім того, необхідно стежити, щоб у зіпсовані бюлетені не відкинули хороші або так звані «спірні» бюлетені (не за формою заповнені бюлетені, де ясно виражена воля виборця на підтримку того або іншого кандидата. Вони можуть бути визнані дійсними).

Фальсифікації шляхом підміни деякої кількості бюлетенів бюлетенями, заповненими на користь бажаного кандидата, можуть вироблятися у двох варіантах. По-перше, можна вилучити деяку кількість бюлетенів, заповнених на користь якогось одного небажаного кандидата, і замінити їх рівною (або приблизно рівною) кількістю бюлетенів, заповнених на користь бажаного кандидата. У цьому випадку показник активності виборців не зміниться, не зміняться й долі бюлетенів, визнаних недійсними.

Іншим поширеним варіантом подібного типу фальсифікації є підміна деякої кількості випадково відібраних бюлетенів, заповнених на користь 
різних кандидатів, на приблизно рівну кількість бюлетенів, заповнених на користь бажаного кандидата. Технічно такий спосіб фальсифікації відповідає підміні виборчих урн. У цьому випадку урна з опущеними туди бюлетенями, поданими за різних кандидатів, замінюється заздалегідь приготованою урною, наповненою бюлетенями на користь бажаного кандидата;

- вилучення бюлетенів, заповнених на користь небажаних кандидатів. Останнім часом розвиток сучасних технологій викликав появу все більш витончених способів фальсифікації виборів: бюлетені просочують спеціальним розчином у клітинці напроти неугодного прізвища, після проставляння ручкою будь-якої відмітки через деякий час вона безслідно зникає. «Порожні» бюлетені, природно, визнаються недійсними. Інший варіант цього способу - ручки з чорнилом, що зникає;

- «віртуальні» порушення, коли в підсумковий протокол заносяться такі цифри тих, що голосували за кандидатів або підсумки референдуму, які здаються бажаними членам виборчих комісій, незважаючи на реальні результати референдумів або виборів.

У поодиноких випадках з метою визнання виборчих бюлетенів недійсними злочинці намагаються знищити або зіпсувати виборчу скриньку. Знищення скриньки з бюлетенями - це приведення ії в повну непридатність до використання за цільовим призначенням: припинення їх (скриньки й бюлетенів) існування як речей матеріального світу (спалювання); руйнування іншим чином, що унеможливлює встановлення змісту виборчих бюлетенів, які були опущені виборцями до скриньок. Псування зазначеної скриньки передбачає пошкодження іiі та бюлетенів, що знаходяться в ній, унаслідок чого вони стають непридатними для використання за цільовим призначенням.

Такі дії спрямовані на недопущення підрахунку бюлетенів відповідно до поданих виборцями голосів, у результаті чого виявлена виборцями на виборах воля виборців не враховується. Таким способом виборці позбавляються права голосу. До таких заходів удаються в тих випадках, коли не вдалося вплинути на волевиявлення виборців в інший спосіб, або для визнання голосування на конкретній дільниці недійсним. Для пошкодження та знищення виборчих бюлетенів можуть використовуватись такі засоби, як фарба, кислота, легкозаймиста речовина тощо.

Зазначені дії вимагають від його виконавців особливої зухвалості, оскільки, як правило, злочин учинюється відкрито в приміщенні для голосування, тобто в присутності багатьох людей - членів виборчої комісії, виборців, офіційних спостерігачів, довірених осіб кандидатів, представників засобів масової інформації тощо [2].

2. Фальсифікація виборів за участю виборців.

Друга категорія правопорушень, пов'язаних із фальсифікацією результатів виборів, передбачає участь виборців принаймні до деякої міри в самому процесі правопорушення. Типовими способами цих правопорушень $є$ такі.

Підкуп голосів. Підкуп у цьому випадку виражається в схилянні виборця чи іншого суб'єкта виборчого процесу шляхом надання матеріальної винагороди до голосування «за» або «проти» чи схилення кандидата до 
зняття своєї кандидатури з голосування. Підкуп застосовується службовими особами, представниками й прибічниками окремих кандидатів та іншими особами в багатьох регіонах країни, що свідчить про масовий характер його застосування. Підкуп може буті спрямований стосовно виборця, члена виборчої комісії, кандидата на виборну посаду в органи державної влади чи органи місцевого самоврядування, а також його довіреної особи, офіційного представника чи будь-якої іншої особи, яка бере участь у виборчому процесі [3].

Загальний механізм підкупу передбачає передачу особі грошей, інших цінностей, надання їй будь-яких переваг, пільг майнового характеру або обіцянки майнових вигод чи позбавлення майнових витрат як винагороди за зміну свого волевиявлення в участі у виборах або за відмову від такої участі.

Спостерігаються різноманітні вияви підкупу. В одних випадках ті, хто має намір здійснити підкуп виборців, підшукують людину, яка знає багато жителів певної місцевості та якій довіряють. I ця людина безпосередньо агітує жителів для голосування за певного кандидата за винагороду. В інших випадках спостерігаються факти так званих «каруселей», які полягають у скуповуванні у виборців незаповнених виборчих бюлетенів і передачі їм для голосування бюлетенів зі зробленою позначкою на користь певного кандидата.

1. «Голосуй за друга»- члени виборчої комісії можуть дозволити родичам голосувати за двома й більше паспортами відсутніх осіб.

2. «Міграційне голосування» (або виборець, що міняє місце про-живання).

3. Надання «допомоги» виборцеві, коли бажання виборців ігно-руються й не враховуються.

4. «Карусель». «Оброблені» люди виносять із ділянки чистий бю-летень, інші люди його «грамотно» заповнюють, передають наступному «обробленому», той кидає його в урну, виносить чистий і так по колу;

5. Голосування за паспортними даними. Якщо виборчим комісіям будуть відомі не лише ПІБ та адреси виборців, а і їхні паспортні дані, то не виключено, що недобросовісні члени комісій зможуть унести до журналу за виборців, що не прийшли на ділянку, їхні дані, узяти бюлетень і проголосувати. Сьогодні отримати паспортні дані не становить особливих труднощів, оскільки такі дані необхідні для оформлення кредиту, для укладення договору про послуги зв'язку тощо. Якщо недобросовісні кандидати підкуповують членів виборчої комісії, вони можуть «домовитися» 3 «потрібними» людьми, які мають у своєму розпорядженні базу даних зареєстрованих у них клієнтів із їхніми паспортними даними.

6. «Чарівна урна». Виїзне голосування вдома (якщо в ньому не беруть участі спостерігачі). Розраховано на інвалідів і літніх людей із поганим зором і слухом. Їм можна послужливо підказати, де поставити галочку (хоча законом це заборонено).

7. «Бригада-УХ». Виїзна бригада з урною може взяти із собою велику кількість бюлетенів і заяв про голосування вдома і влаштувати поквартирний обхід будинків для підвищення явки. 
8. «Пустушка» - члени виборчої комісії можуть видавати для голосування бюлетені, що не мають підписів членів виборчої комісії та їі печатки. Згідно із законом, такі бюлетені вважаються недійсними. Тобто голос виборця не зараховується.

Допустимо, фальсифікація полягає в підкиданні додаткових бюлетенів на користь бажаного кандидата. Тоді активність (явка) виборців, яка спостерігається, буде вищою за середню активність у регіоні. Аналогічний ефект спостерігатиметься, якщо виборчі комісії деякого рівня припишуть голоси якому-небудь кандидатові або партії. У цьому випадку, щоб цифри в протоколі підрахунку голосів збігалися, фальсифікатори не повинні забувати додати таке саме число в графи «число виборців, що отримали бюлетені», «число знайдених в урні бюлетенів», «число бюлетенів, визнаних дійсними». Інакше сумарне число бюлетенів, поданих за всіх кандидатів, i зіпсованих бюлетенів буде більше, ніж число бюлетенів, знайдених в урні.

Також варто зосередити увагу на деяких проблемах фінансування виборчих кампаній як можливому джерелі фінансування подальших витрат на здійснення фальсифікацій результатів виборів. Результат виборів значно залежить від того, якими коштами володіє партія або кандидат, оскільки виборча кампанія, а саме передвиборча агітація, проводиться за рахунок останніх.

Партії (блоки) та кандидати самі оплачують проведення мітингів і зборів, видання агітаційних плакатів, листівок та інших агітаційних і організаційних заходів. Варто зазначити, що кошти значно впливають на результат виборів.

Висновки. Способи використання фінансової (матеріальної) підтримки залежать від виду такої підтримки (кошти, майно, будь-які послуги). Якщо такою підтримкою є кошти, то їх використання виражається у формі їх використання як засобу платежу для оплати товарів, робіт, послуг, безоплатної передачі їх іншим особам. Матеріальна підтримка у вигляді матеріальних цінностей може полягати в користуванні таким майном чи розпорядження ним у цивільно-правовому розумінні, зокрема будь-якому відчуженні (наприклад, передачі виборцям як предмета їх підкупу користування транспортними засобами, будівлями, приміщеннями) [1].

\section{Література}

1. Андрушко П.П. Злочини проти виборчих прав громадян та їх права брати участь у референдумі: кримінально-правова характеристика / П.П. Андрушко. - К. : КНТ, 2007.

2. Мельник M.І. Кримінальна відповідальність за злочини проти виборчих прав / M.I. Мельник. - К. : Атіка, 2005.

3. Науково-практичний коментар Кримінального кодексу України від 5 квіт. 2001 р. / [M.I. Мельник, М.I. Хавронюк та ін.]. - К. : Каннон, А.С.К., 2001.

4. Мельничук О.С. Словарь иностранных слов / О.С. Мельничук. К., 1974. 


\section{Ано т а ц я}

Чумак С. П. Особливості способів учинення злочинів, пов'язаних із фальсифікацією результатів виборів. - Стаття.

Стаття присвячена окремим особливостям способів фальсифікації результатів виборів за участю різних суб’єктів виборчого процесу.

Ключові слова: вибори, способи, фальсифікація, підробка, «виборчі бюлетені».

\section{Анн о т а ци я}

Чумак С. П. Особенности способов совершения преступлений, связанных с фальсификацией результатов выборов. - Статья.

Статья посвящена отдельным особенностям способов фальсификации результатов выборов с участием различных субъектов избирательного процесса.

Ключевые слова: выборы, способы, фальсификация, подделка, «избирательные бюллетени».

\section{S u m m a r y}

Chumak S. P. Features of ways of committing crimes related to falsification of election results. - Article.

The article is devoted to individual features means rigging the elections with the participation of different actors of the electoral process.

Key words: elections, methods, falsification, forgery, "ballot papers". 